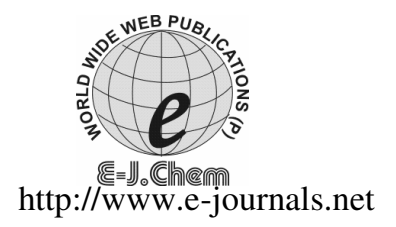

\title{
A Rapid and Direct Sensitive Spectrophotometric Method for the Determination of Molybdenum(VI) using Gallacetophenone Phenylhydrazone with Application to Alloy Steel Samples
}

\author{
D.VENKATARAMANA REDDY*, \\ P.V. CHALAPATHI ${ }^{\S}$ and A.VARADA REDDY \\ *S.G. Govt. College, Piler-517 214, India \\ ${ }^{\S}$ Sri Venkateswara Arts College, Tirupati, India \\ Analytical Division, Department of Chemistry \\ S.V. University, Tirupati - India \\ chemdvrr@yahoo.com
}

Received 22 September 2010; Revised 3 December 2010; Accepted 16 December 2010

\begin{abstract}
A rapid, sensitive and fairly selective spectrophotometric method has been developed for the determination of molybdenum(VI) using gallacetophenone phenylhydrazone (GPPH) as an analytical reagent. The GPPH forms an orange red species of molybdenum(VI) at a $\mathrm{pH}$ range of 3.0-4.0 and the complex is soluble in $20 \%$ ethanol. The Mo(VI)-GPPH complex shows maximum absorbance at $375 \mathrm{~nm}$ with molar absorptivity and Sandell's sensitivity being $1.539 \times 10^{4} \mathrm{~L} / \mathrm{mol} \mathrm{cm}$ and $1.5 \times 10^{-3} \mu \mathrm{g} \mathrm{cm}^{-2}$ respectively. The system obeys Beer's law in the range of $1.0-6.0 \mu \mathrm{g} / \mathrm{mL}$. The repeatability of the method was checked by finding the relative standard deviation. The composition of the Mo(VI)-GPPH complex is established as 1:2 by slope analysis method. The instability constant of the complex calculated from Edmond and Birnbaum's method is $6.785 \times 10^{-8}$ at room temperature. The interfering effect of various cations and anions has also been studied. The method has been applied for the determination of Mo(VI) in alloy steel samples.
\end{abstract}

Keywords: Molybdenum(VI)-GPPH complex, Spectrophotometry, Beer's law, Slope analysis method, Alloy steel samples

\section{Introduction}

Molybdenum is one of the most important element for many organisms and is widely distributed in nature ${ }^{1}$. It can exist in several oxidation states ranging from 0 to VI, where VI 
is the most common form found in agricultural soils ${ }^{2}$. Molybdenum is commercially important in metallurgical and agricultural laboratories. Besides its widespread industrial uses, molybdenum is an essential trace element required by both plants and animals. For the determination of molybdenum at trace amount levels, there are several frequently adopted methods using analytical techniques such as atomic absorption spectroscopy (AAS), ICP-AES, ICP-MS, x-ray fluorescence spectroscopy, spectrofluorimetry, spectrophotometry and other techniques ${ }^{3-5}$. Among these, spectrophotometric methods are most commonly used for the determination of molybdenum in developing countries because these are cheaper and easier to handle with comparable accuracy.

At present, a number of reagents are used for determining molybdenum in microgram quantities but only a limited number of organic reagents are useful for separation and determination of molybdenum ${ }^{6-9}$. However, some of these reagents show poor selectivity and sensitivity. Gallacetophenone phenylhydrazone has excellent analytical characteristics and offers advantages of high sensitivity, selectivity and simplicity for the determination without the need for organic solvent extraction, pre concentration or pre separation, unlike some of the reagents reported.

The review of the literature revealed that only a few oximes and thiosemicarbazones were employed for the determination of molybdenum ${ }^{10-14}$. The review of the methods indicated that no aryl phenylhydrazone has been so far employed for the determination of molybdenum. Hence, the authors are prompted to introduce a new reagent, gallacetophenone phenylhydrazone (GPPH) for the direct spectrophotometric determination of $\mathrm{Mo}(\mathrm{VI})$.

\section{Experimental}

A SHIMADZU 240 UV-visible spectrophotometer with $1.0 \mathrm{~cm}$ quartz cell was used for absorbance studies. An ELICO LI-120 digital $\mathrm{pH}$ meter was used for $\mathrm{pH}$ adjustment in the present investigation. All reagents used were of analytical reagent grade, unless otherwise stated.

Preparation of standard solution of molybdenum(VI)

$0.025 \mathrm{M}$ molybdenum(VI) solution was prepared by dissolving $1.103 \mathrm{~g}$ of ammonium molybdate in distilled water containing few drops of ammonia. The solution was made up to $250 \mathrm{~mL}$ and standardized gravimetrically by the oxine method ${ }^{15}$. Working solutions were prepared by appropriate dilution of the stock solution.

Preparation of gallacetophenone phenylhydrazone

Gallacetophenone phenylhydrazone was prepared as per the standard procedure given by Blatt ${ }^{16}$ and Curniss et $a l^{17}$. The purity of the reagent was checked by melting point and elemental analysis. The melting point is $146-147^{\circ} \mathrm{C}$. A $1.043 \times 10^{-2} \mathrm{M}$ reagent solution was prepared in $95 \%$ ethanol just before use.

\section{Buffer solutions}

Solutions of $0.5 \mathrm{M}$ sodium formate and $0.5 \mathrm{M}$ formic acid were prepared in distilled water. Suitable portions of the solutions were mixed to get the desired $\mathrm{pH}$.

\section{Preparation of solutions of alloy steel samples}

An accurately weighed amount of alloy steel sample $(0.5 \mathrm{~g})$ was dissolved completely in minimum amount of aquaregia by slow heating on sand bath and then heated to fumes of oxides of nitrogen. After cooling, $5 \mathrm{~mL}$ of $1: 1 \mathrm{H}_{2} \mathrm{SO}_{4}: \mathrm{H}_{2} \mathrm{O}$ mixture was added and evaporated to dryness. Sulphuric acid treatment was repeated three times to remove all the 
nitric acid. The residue was dissolved in $20 \mathrm{~mL}$ of distilled water and filtered and filtrate was made up to $100 \mathrm{~mL}$ in a calibrated volumetric flask with distilled water. The sample solution was approximately diluted to obtain the concentration in the required range.

\section{General procedure}

To $1 \mathrm{~mL}$ of a working standard solution containing $1.043 \times 10^{-3} \mathrm{M}$ molybdenum(VI), $1 \mathrm{~mL}$ of $1.043 \times 10^{-2} \mathrm{M}$ reagent solution and $5 \mathrm{~mL}$ of sodium formate-formic acid buffer ( $\mathrm{pH} 3.5$ ) were added. The mixture was transferred into a $20 \mathrm{~mL}$ volumetric flask and diluted to the mark with ethanol. The ethanol concentration was maintained at $25 \% \mathrm{v} / \mathrm{v}$ and then the absorbance was measured at $375 \mathrm{~nm}$ against the reagent blank.

\section{Results and Discussion}

Molybdenum(VI) reacts with gallacetophenone phenylhydrazone to form an orange red 1:2 complex in sodium formate-formic acid buffer of $\mathrm{pH}$ 3.5. The complex is soluble in ethanol and its concentration is maintained at $25 \% \mathrm{v} / \mathrm{v}$. The complex has a maximum absorbance at $375 \mathrm{~nm}$ and is stable for more than $48 \mathrm{~h}$. The influence of various factors such as $\mathrm{pH}$, reagent concentration and influence of diverse ions is studied in order to develop a rapid, sensitive and selective spectrophotometric method for the determination of molybdenum(VI) in trace levels.

\section{Absorption spectra}

The absorption spectrum of the Mo(VI)-GPPH complex was recorded against the reagent blank. Similarly the absorption spectrum of the reagent was recorded against the ethanol as blank. The absorption spectra of both the reagent and complex are shown in Figure 1. The spectra obtained reveal that the reagent has a minimum absorbance at the maximum absorbance of the complex and hence does not interfere with the determination of molybdenum. Hence, all the absorbance measurements of the complex were made at $375 \mathrm{~nm}$.

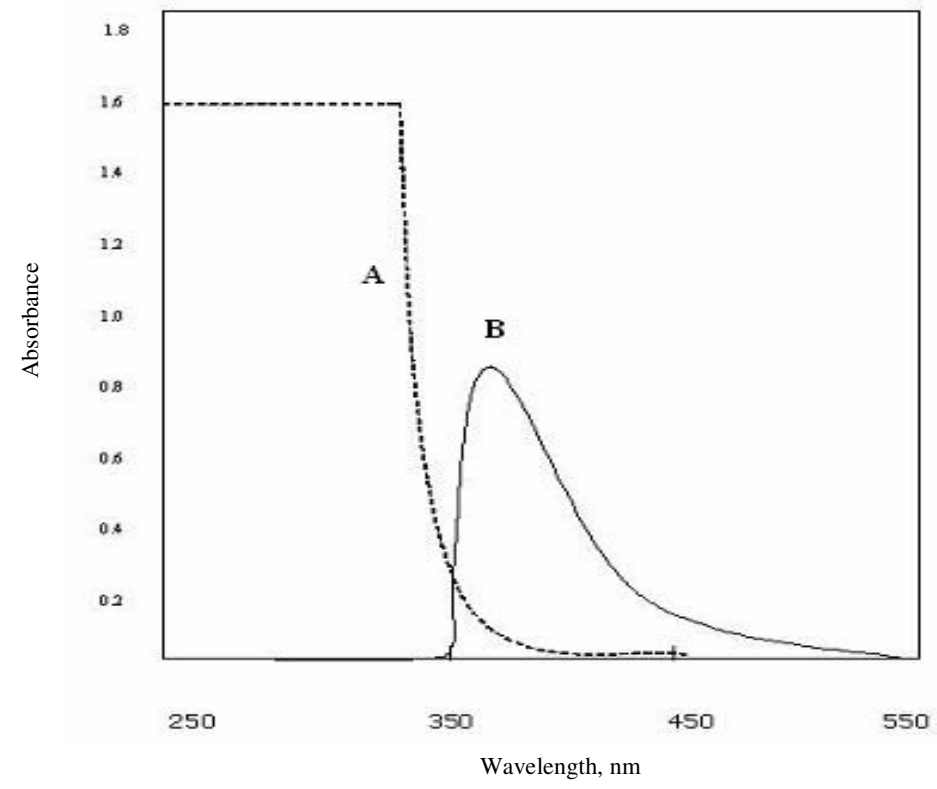

Figure 1. (a) Absorption spectrum of GPPH vs. ethanol blank (b) Absorption spectrum of Mo(VI)-GPPH complex vs. reagent blank 


\section{Effect $p H$}

The influence of $\mathrm{pH}$ on the Mo(VI)-GPPH complex was studied to find out the optimum $\mathrm{pH}$ range for molybdenum determination. In each instance, a mixture containing $2.5 \mathrm{~mL}$ of $1.043 \times 10^{-3} \mathrm{M}$ $\mathrm{Mo}(\mathrm{VI}), 2.5 \mathrm{~mL}$ of $1.043 \times 10^{-2} \mathrm{M}$ reagent solution, $10 \mathrm{~mL}$ of alcohol and appropriate amounts of buffer of various $\mathrm{pH}$ values (2.0-3.0 potassium chloride-hydrochloric acid, 3.5-4.0 sodium formate-formic acid and 4.5-5.0 sodium acetate-acetic acid) were taken and made up to $50 \mathrm{~mL}$ with distilled water. The absorbances of the solutions were measured at $375 \mathrm{~nm}$ against their corresponding reagent blanks and the results are shown in Table 1. A plot drawn between the various $\mathrm{pH}$ values and their absorbances is shown in Figure 2. The system exhibits constant absorbance in the $\mathrm{pH}$ range 3.0-4.0. Hence all the subsequent studies were carried out at $\mathrm{pH} 3.5$.

Table 1. Effect of $\mathrm{pH}$

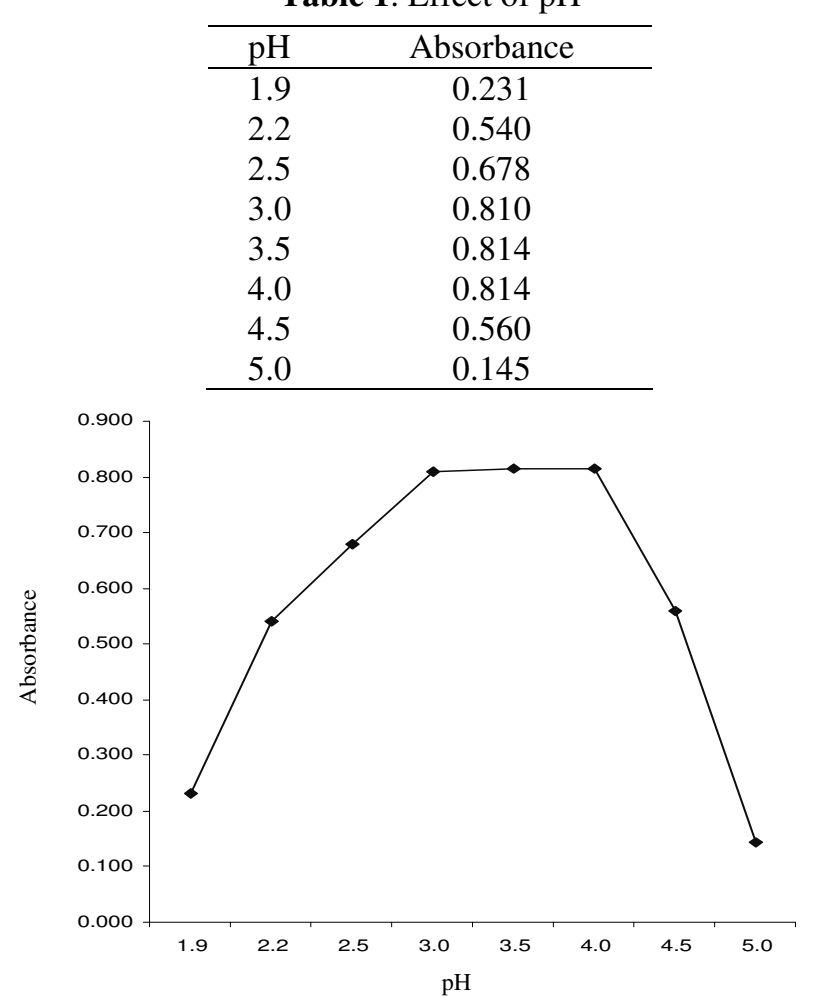

Figure 2. Effect of $\mathrm{pH}$ on absorbance of $\mathrm{Mo}(\mathrm{VI})-\mathrm{GPPH}$ complex

\section{Effect of reagent concentration}

The effect of reagent concentration was studied by keeping $1 \mathrm{~mL}$ of $1.043 \times 10^{-3} \mathrm{M}$ molybdenum(VI) solution and $5 \mathrm{~mL}$ of $\mathrm{pH} 3.5$ sodium formate-formic acid buffer solution constant. The concentration of reagent solution was varied from $0.5 \times 2.086 \times 10^{-3}$ to $10 \times 2.086 \times 10^{-3} \mathrm{M}$ to obtain maximum color development. The total volume of solution was brought to $20 \mathrm{~mL}$ maintaining alcohol concentration $25 \% \mathrm{v} / \mathrm{v}$. The absorbances of these solutions were measured at $375 \mathrm{~nm}$ against the reagent blank. The results showed that a ten fold molar excess of the reagent to that of the metal was sufficient for maximum color development of the complex. Hence, a 10 fold molar excess of the reagent was maintained for the method. 


\section{Validity of Beer's law, molar absorptivity, Sandell's sensitivity}

Different aliquots of Mo(VI) ion solution containing 1.0-10.0 $\mu \mathrm{g} / \mathrm{mL}$ are used for the studies and the data are recorded in Table 2. The present studies indicate that Beer's law is obeyed for molybdenum(VI) over the concentration range 1.0-6.0 $\mu \mathrm{g} / \mathrm{mL}$ as shown in Figure 3. The molar absorptivity of the complex was calculated to be $1.539 \times 10^{4} \mathrm{~L} / \mathrm{mol}$. cm and Sandell's sensitivity of the complex obtained from Beer's law data for absorbance, 0.001 was found to be $0.00625 \mu \mathrm{g} \mathrm{cm}^{-2}$.

Table 2. Validity of Beer's law on Mo(Vi)-GPPH complex

\begin{tabular}{cc}
\hline Amount of $\mathrm{Mo}(\mathrm{VI}), \mu \mathrm{g} / \mathrm{mL}$ & Absorbance \\
\hline 1.0 & 0.159 \\
2.0 & 0.326 \\
3.0 & 0.486 \\
4.0 & 0.648 \\
5.0 & 0.812 \\
6.0 & 0.955 \\
7.0 & 1.091 \\
8.0 & 1.208 \\
9.0 & 1.300 \\
10.0 & 1.381 \\
\hline
\end{tabular}

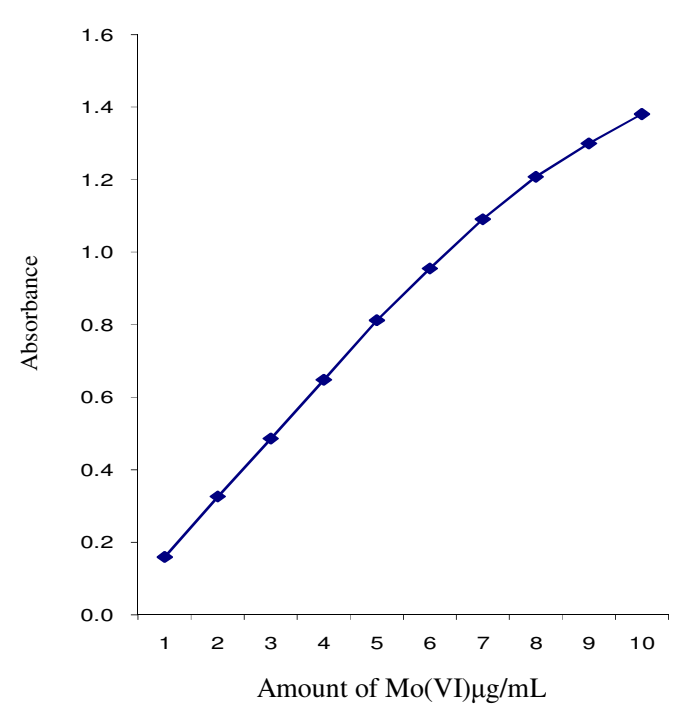

Figure 3. Validity of Beer's law on Mo(VI)-GPPH complex

\section{Ringbom plot for Mo(VI)-GPPH complex}

A Ringbom plot is the established standard method adopted to know the optimum range of concentration for a system that obeys Beer's law. From the data of Table 3, a plot was drawn between $\log \mathrm{C}$ of molybdenum(VI) and (l-T) where ' $\mathrm{T}$ ' is the transmittance. The plot has a sigmoid shape with a linear segment at intermediate absorbance values (0.5-0.8) and concentration values $(3.3-3.8 \mu \mathrm{g} / \mathrm{mL})$. The slope of the Ringbom plot from Figure 4 is 0.788 . Hence, the ratio between the relative error in concentration and photometric error is 2.92 . And hence, for a photometric error of $1 \%, \Delta \mathrm{P}=0.01$, the relative error in concentration is 0.0292 . 
Table 3. Ringbom plot of Mo(Vi)-GPPH complex

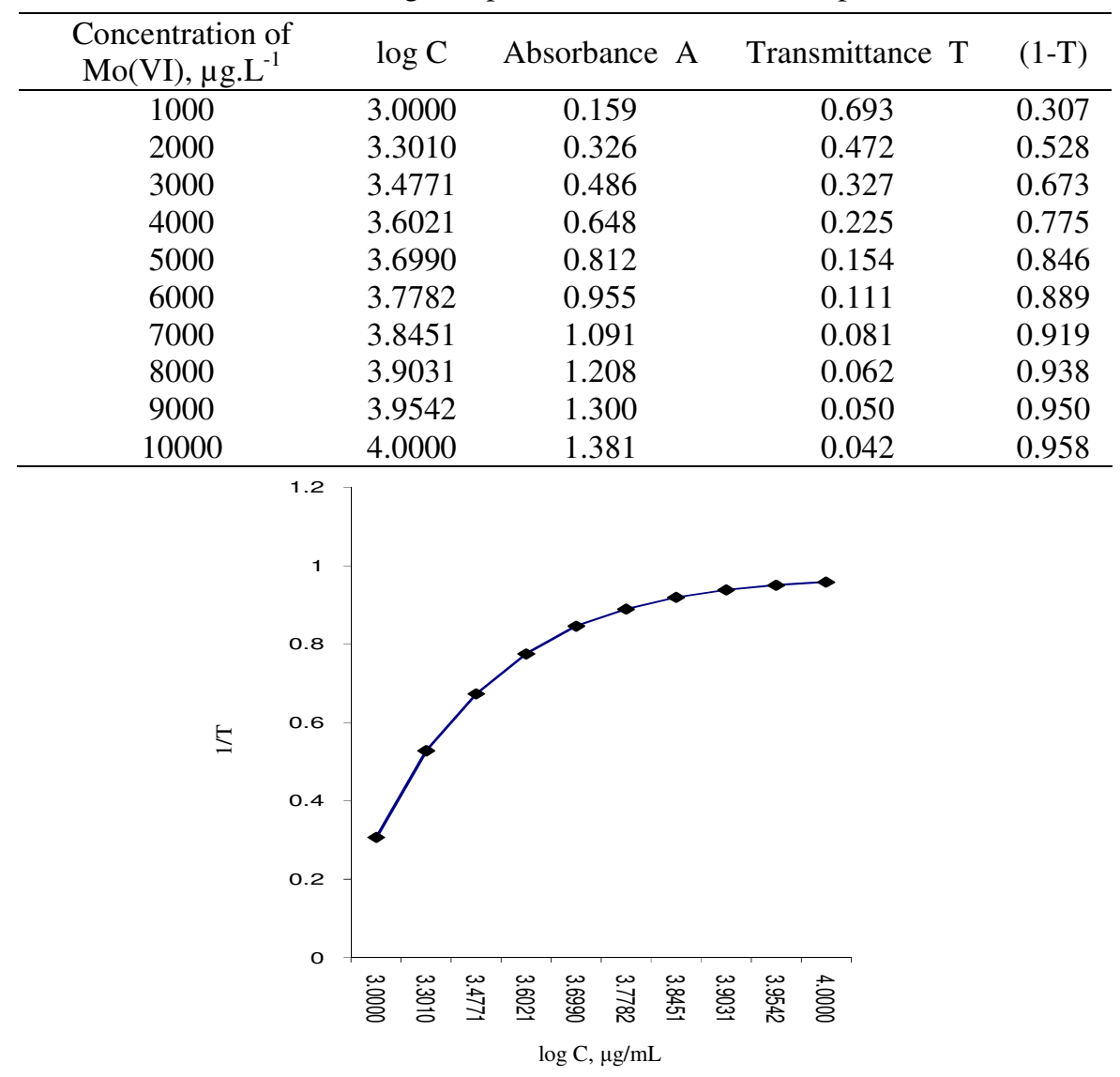

Figure 4. Ringbom plot of Mo(VI)-GPPH complex

\section{Precision and accuracy of the method}

The method has good reproducibility for a set of ten measurements of $4.0 \mu \mathrm{g} / \mathrm{mL}$ of Mo(VI) under optimum conditions. Calculations reveal that the standard deviation of method is $0.0015 \mu \mathrm{g} / \mathrm{mL}$ and the relative standard deviation is $0.23 \%$. These values indicate that this method has the highest accuracy and precision.

\section{Determination of composition of Mo(VI)-GPPH complex}

The composition of the Mo(VI)-GPPH complex was determined by slope ratio method and it was verified by the Job's method of continuous variation. Two series of mixtures were prepared using $2.086 \times 10^{-3} \mathrm{M}$ solutions of molybdenum(VI) and GPPH.

In one series, the content of $\mathrm{Mo}(\mathrm{VI})\left(2 \mathrm{~mL}\right.$ of $\left.2.086 \times 10^{-3} \mathrm{M}\right)$ was kept constant and then varying volumes $\left(0.2-1.4 \mathrm{~mL}\right.$ of $\left.2.086 \times 10^{-3} \mathrm{M}\right)$ of the reagent solutions were added. To each of these solutions $5 \mathrm{~mL}$ of $\mathrm{pH} 3.5$ buffer was added and finally the volumes made up to $20 \mathrm{~mL}$ with distilled water and maintaining the alcohol concentration at $25 \% \mathrm{v} / \mathrm{v}$. The absorbances of colored solutions were recorded at $375 \mathrm{~nm}$ against their corresponding reagent blanks and the results are shown in Table 4. A graph drawn between the concentration of the reagent and its absorbance is shown in Figure 5. 
In another series, the volume of $2.086 \times 10^{-3} \mathrm{M}$ GPPH was kept constant in excess $(2 \mathrm{~mL})$ and to them, varying volumes $\left(0.2-1.4 \mathrm{~mL}\right.$ of $\left.2.086 \times 10^{-3} \mathrm{M}\right)$ molybdenum(VI) solution were added and the rest of the procedure is the same as described in excess of metal ion. The absorbance values of solutions were recorded at $375 \mathrm{~nm}$ and the results are shown in Table 4 . A plot drawn between the concentration of metal ion and its absorbance is shown in Figure 5. The above two plots indicate that the composition of the complex is 1:2 (M:L). The composition of the complex is verified thoroughly by Job's method of continuous variation.

Table 4. Slope ratio method for the determination of composition of Mo(Vi)-GPPH complex

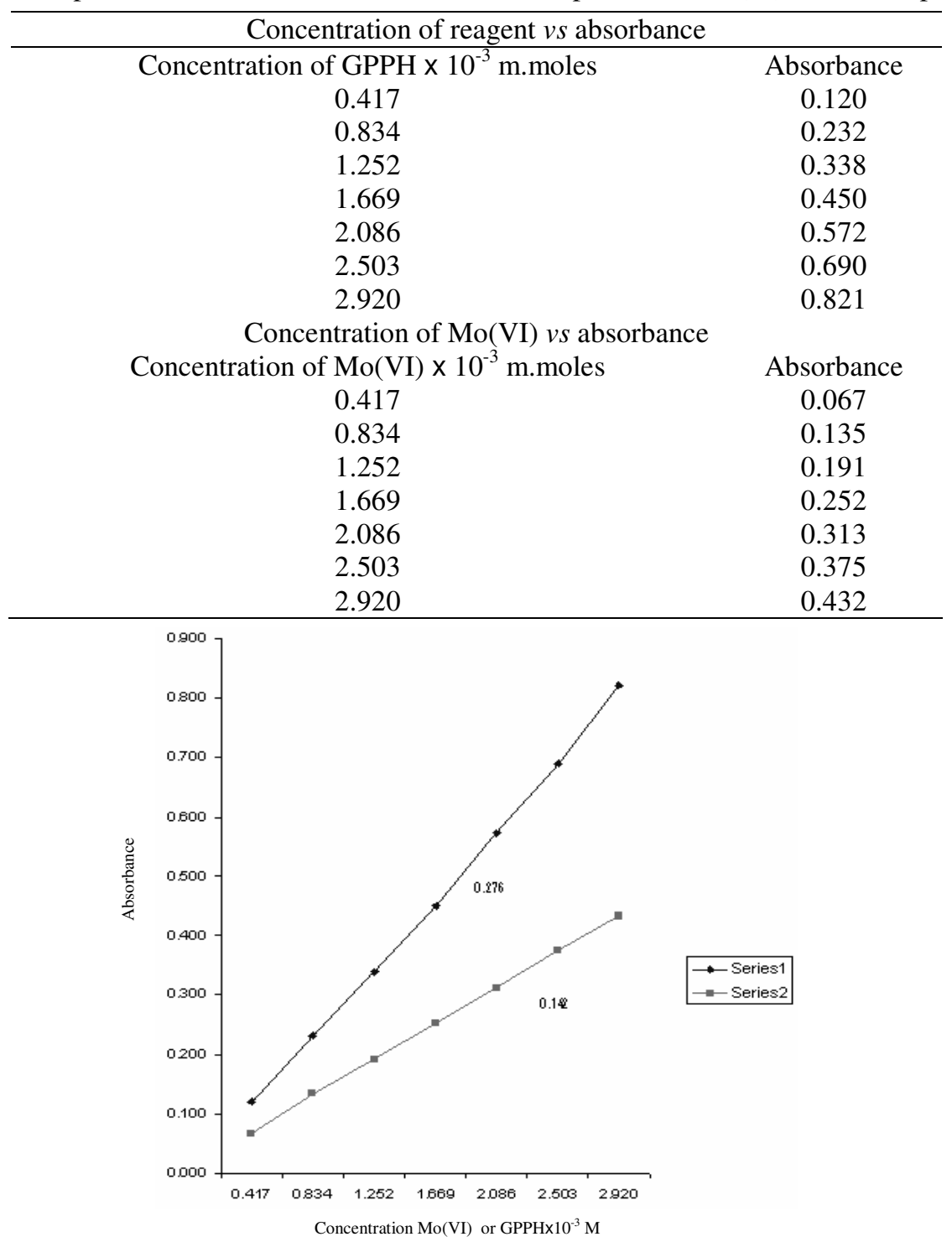

Figure 5. Slope ratio method series1. Concentration GPPH vs. absorbance series 2. Concentration $\mathrm{Mo}(\mathrm{VI})$ vs. absorbance 


\section{Calculation of instability constant of Mo(VI)-GPPH complex}

Edmonds and Birnbaum's method was adopted to determine the instability constant of the Mo(VI)-GPPH complex. The absorbance values of solutions containing the fixed amounts of molybdenum(VI) $\left(0.522 \times 10^{-4} \mathrm{M}\right)$, buffer $(\mathrm{pH} 3.5)$ and different known concentrations $\left(3.129 \times 10^{-4}\right.$ $4.172 \times 10^{-4} \mathrm{M}$ ) of reagent in alcohol were measured at $375 \mathrm{~nm}$ and data are recorded in Table 5 . The instability constant of Mo(VI)-GPPH complex is calculated and found to be $6.785 \times 10^{-8}$ at room temperature. This value is in perfect agreement with the value obtained by Asmus's method.

Table 5. Instability constant by Edmonds and Birnbaum's method

\begin{tabular}{cccccc}
\hline $\begin{array}{c}\text { Concentration of reagent } \\
\times 10^{-4} \mathrm{M}\end{array}$ & Absorbance & \multicolumn{4}{c}{$\begin{array}{c}\text { Instability constants in pairs } \\
\times 10^{-8}\end{array}$} \\
\hline 3.129 & 0.535 & $1 \& 2$ & $6.979 ; 2 \& 3$ & 6.864 \\
3.389 & 0.57 & $1 \& 3$ & $6.920 ; 2 \& 4$ & 6.933 \\
3.65 & 0.601 & $1 \& 4$ & $6.952 ; 2 \& 5$ & 6.626 \\
3.911 & 0.629 & $1 \& 5$ & $6.728 ; 3 \& 5$ & 6.484 \\
4.172 & 0.651 & $4 \& 5$ & 6.581 & & \\
& Average value $=6.785 \times 10^{-8}$ at $30{ }^{\circ} \mathrm{C}$ & \\
\hline
\end{tabular}

\section{Effect of diverse ions}

Interference of a number of cations and anions was studied to measure the absorbance of the reaction mixture containing $5.0 \mu \mathrm{g} / \mathrm{mL}$ of molybdenum. A change of absorbance of $\pm 2 \%$ was taken as the tolerance limit for interference. It was observed that cations like $\mathrm{Co}(\mathrm{II}), \mathrm{Ni}$ (II), $\mathrm{Zn}$ (II), $\mathrm{Mn}$ (II), $\mathrm{Hg}(\mathrm{II}), \mathrm{Pb}(\mathrm{II}), \mathrm{Cd}(\mathrm{II})$ and $\mathrm{Be}(\mathrm{II})$ do not interfere in the determination. $\mathrm{Cu}$ (II), $\mathrm{Bi}$ (III), $\mathrm{V}(\mathrm{V}), \mathrm{Cr}(\mathrm{VI})$ and $\mathrm{W}(\mathrm{VI})$ interfere seriously. The interference $\mathrm{Al}(\mathrm{III}), \mathrm{Fe}(\mathrm{III}), \mathrm{Ti}(\mathrm{IV})$ and $\mathrm{U}(\mathrm{VI})$ can be masked by the addition of sodium fluoride and thus an increased tolerance limit was achieved. Among the anions tested oxalate, citrate tartarate and EDTA interfere in the determination by bleaching the colour. Interestingly fluoride ion which interfered seriously in the determination of Ti(IV) and $\mathrm{Al}(\mathrm{III})$ shows no effect on the determination of $\mathrm{Mo}(\mathrm{VI})$. Hence, fluoride ion is utilized to mask the metal ions like $\mathrm{Al}(\mathrm{III}), \mathrm{Fe}(\mathrm{III}), \mathrm{Ti}(\mathrm{IV})$ and $\mathrm{U}(\mathrm{VI})$ in the determination of Mo(VI). The proposed method, when compared with other spectrophotometric methods (Table 6) is found to be more sensitive and selective. It also offers advantages like reliability and reproducibility in addition to its rapidness, simplicity, instant color development and less interference.

Table 6. Comparison of the present method with other reported spectrophotometric methods for determination for Mo(VI)

\begin{tabular}{|c|c|c|c|c|c|}
\hline Reagent & $\begin{array}{c}\text { Optimu } \\
\mathrm{m} \text { pH } \\
\text { range }\end{array}$ & $\begin{array}{c}\lambda_{\max } \\
\mathrm{nm}\end{array}$ & $\begin{array}{c}\text { Beer's } \\
\text { law range } \\
\text { ppm }\end{array}$ & $\begin{array}{c}\text { Molar } \\
\text { absorptivity } \\
\text { L/mol. cm } \\
\end{array}$ & [Ref ] \\
\hline $\begin{array}{l}\text { 3',5'-Dichloro-2'-hydroxy } \\
\text { acetophenone oxime }\end{array}$ & $2.5-3.5$ & 400 & $2.0-18.0$ & 510 & {$[10]$} \\
\hline 2,4-Dihydroxyacetophenone oxime & $2.0-4.0$ & 400 & - & - & [11] \\
\hline 2-Hydroxy-1-naphthaldoxime & $2.5-3.5$ & 400 & - & 1750 & {$[12]$} \\
\hline $\begin{array}{l}2,2^{\prime} \text {-Dihydroxybenzophenone } \\
\text { thiosemicarbazone }\end{array}$ & $0.7-1.8$ & 500 & $1.0-22.0$ & 3300 & [13] \\
\hline $\begin{array}{l}\text { 1,4-Dihydroxyphthalimide } \\
\text { dithiosemicarbazone }\end{array}$ & $2.5-3.5$ & 400 & $1.0-10.0$ & 9400 & [14] \\
\hline $\begin{array}{l}\text { 2,6-Diacetyl pyridine bis-4- } \\
\text { phenyl-3-thiosemicarbazone }\end{array}$ & 3.5 & 500 & $0.9-9.0$ & 12121 & [15] \\
\hline $\begin{array}{l}\text { Gallacetophenone } \\
\text { phenylhydrazone }\end{array}$ & $3.0-4.0$ & 375 & $1.0-6.0$ & 15400 & $\begin{array}{l}\text { Present } \\
\text { method }\end{array}$ \\
\hline
\end{tabular}




\section{Applications}

The validity of the method was tested with standard alloy steel samples. The results are shown in Table 7.

Table 7. Determination of Mo(VI) in alloy steel samples

\begin{tabular}{ccc}
\hline Alloy sample & Mo certified, \% & Mo found, \% \\
\hline BAS 33b & 0.40 & 0.41 \\
BAS 64b & 4.95 & 4.94 \\
BCS 219 & 0.58 & 0.62 \\
BCS 406 & 1.0 & 1.03 \\
\hline
\end{tabular}

\section{Conclusion}

The present investigations proved that GPPH is a promising complexing agent for Mo(VI) and its subsequent determination by spectrophotometry is rapid and precise. The method has good sensitivity when compared to the other existing spectrophotometric determination methods. The selectivity of this method is improved by using making agents for $\mathrm{Al}(\mathrm{III})$, $\mathrm{Fe}(\mathrm{III}), \mathrm{Ti}(\mathrm{IV})$ and U(VI). It has been successfully applied for the determination of Mo(VI) in alloy steel samples.

\section{Acknowledgment}

One of the authors, D. Venkataramana Reddy is grateful to University Grants Commission, New Delhi for financial assistance in the form of an award of Senior Research Fellowship.

\section{References}

1. Hoshi S, Konuma K, Sugawara K, Uto M and Ataksuka K, Talanta, 1997, 44(8), 1473-1478.

2. Kaiser B N, Gridley K L, Brady J N, Phillips T and Tyerman S D, J Ann Bot., 2005, 96(5), 745-754.

3. Hajian R and Shams E, J Iranian Chem Soc., 2006, 3(1), 32-37.

4. Burguera J L and Burguera M, J Anal Chim Acta, 1986, 179, 497-502

5. Matsusaki K, Nomi M, Higa M and Sata T, J Anal Sci., 1999, 15(2), 145-152

6. Filik H, Tutem E and Apak R, J Anal Chim Acta, 2004, 505(1), 77-82

7. Naik B R and Desai K K, Asian J Chem., 2006, 18(4), 3176-3178.

8. Tascioglu S, Sendil O and Beyreli S, J Anal Chim Acta, 2007, 590(2), 217-223

9. Zaijuna L, Yuling Y, Jian T and Jiaomai P, J Food Composition Anal., 2005, 18, 561-169.

10. Lal K and Gupta S P, Curr Sci., 1976, 45, 84.

11. Reddy D V and Reddy V K, Indian J Chem., 1980, 19, 928-929.

12. Lopez, Fernandez J M, Perez-Bendito D and Valcarcel M, Anal., 1978, 103, 1210.

13. Ternero Rodriguez M, Analyst, 1982, 107, 41

14. Reddy S A, Reddy K J, Narayana S L, Rao Y S, Ramachandraiah C and Reddy A V, Food Anal Methods, 2009, 2, 141.

15. Bassett J, Denny R C, Jeffery G H and Mendham J, Vogel's Text Book of Quantitative Inorganic Analysis, Longman, London, $4^{\text {th }}$ Eds, 1978, 47

16. Blatt A H, Organic Synthesis, John Willey, Coll., 1945, 2, 304.

17. Furness B S, Hannaford A J, Rogers V, Smith P W G and Tatchel A R, Vogel's Text Book of Practical Organic Chemistry, Ed Longman, London, $4^{\text {th }}$ Edn, 1978, 886. 


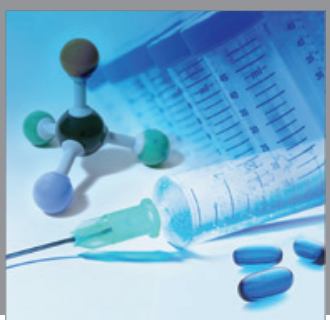

International Journal of

Medicinal Chemistry

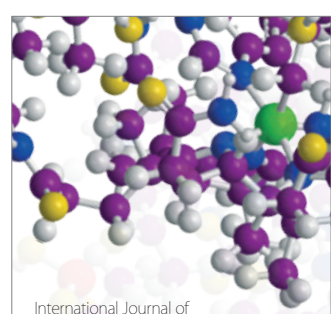

Carbohydrate Chemistry

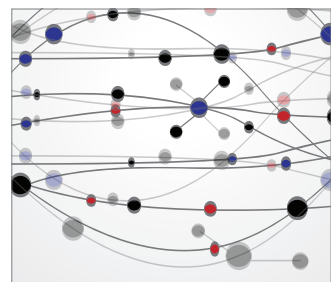

The Scientific World Journal
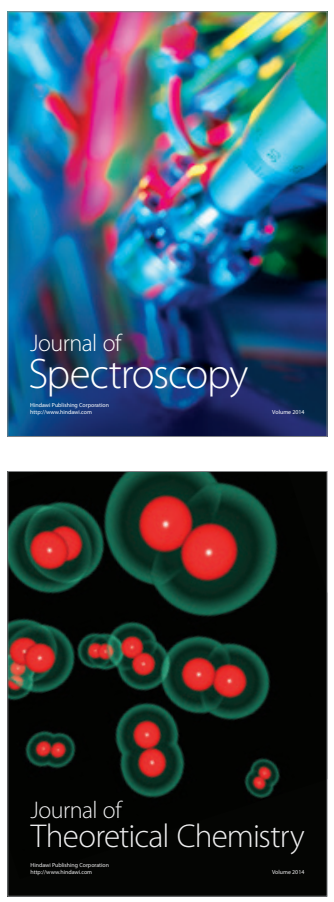
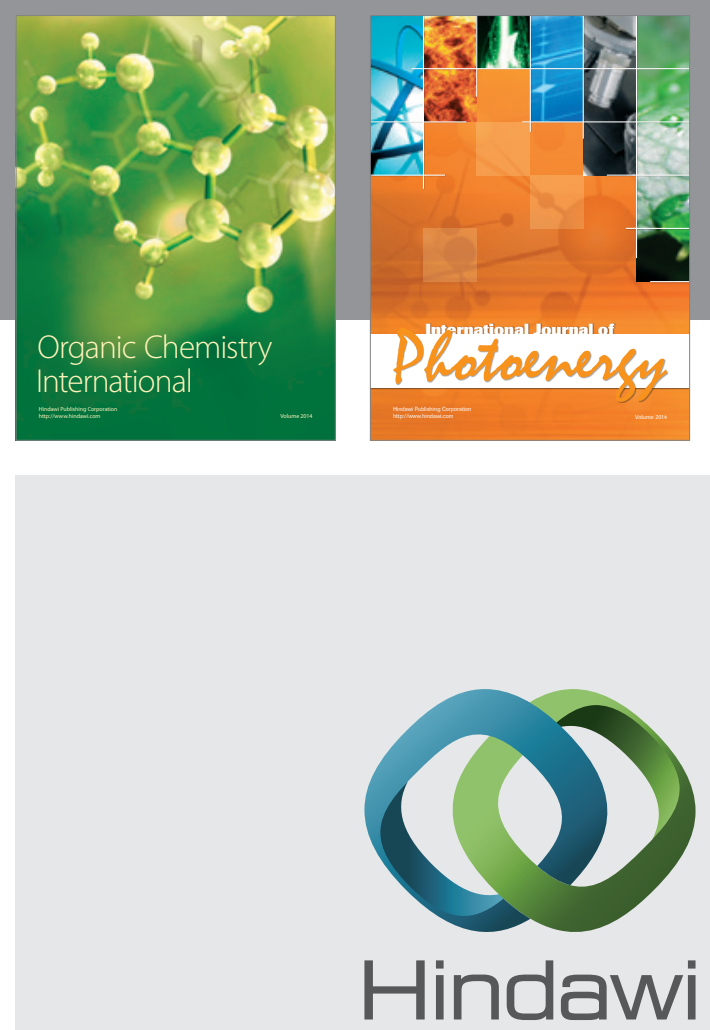

Submit your manuscripts at

http://www.hindawi.com
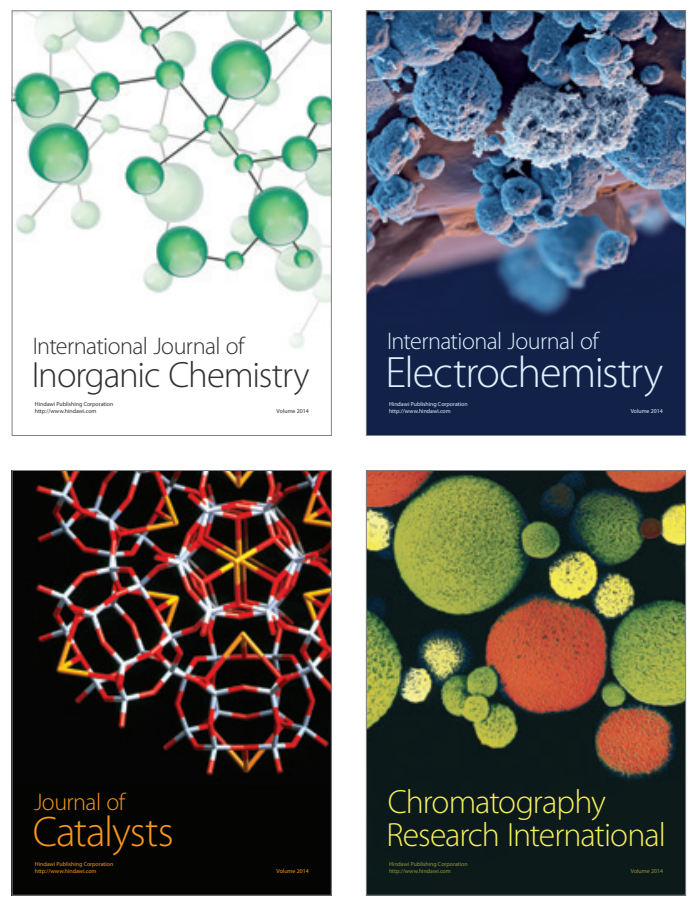
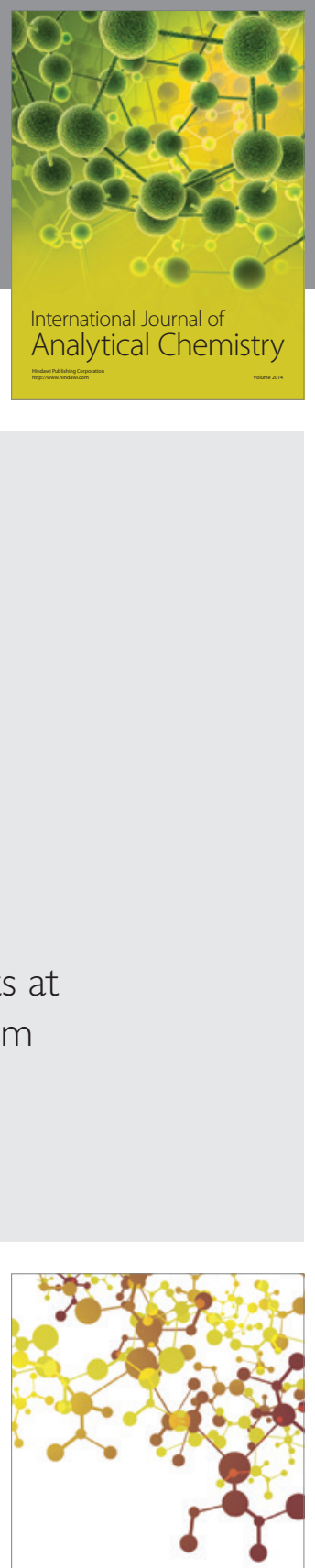

Journal of

Applied Chemistry
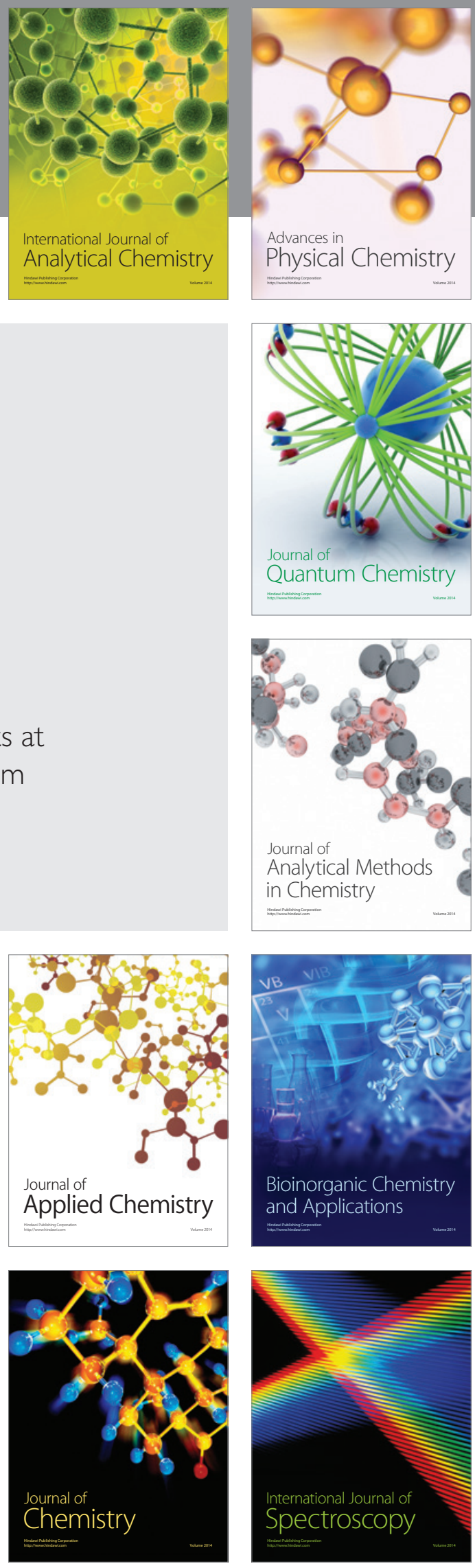